\title{
FASHION IN A TIME OF PANDEMIC
}

\section{Sanja Risteski ${ }^{1 *}$, Vineta Srebrenkoska ${ }^{1}$}

${ }^{1}$ Faculty Technology, University Goce Delcev Stip, Stip, North Macedonia

Review paper

*e-mail: sanja.risteski@ugd.edu.mk

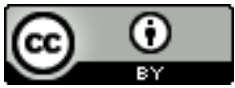

Abstract: The fashion industry has taken a hard hit due to the COVID-19 crisis. From the material to the spiritual. The Pandemic has transformed consumers' relationship with clothes. In this paper, research was conducted on how the Pandemic affected fashion, whether the changes in fashion that occurred as a result of the Pandemic will remain permanent or not. Research on pandemics that have previously affected the world and how they have affected fashion, compared to the Pandemic with COVID-19 was also done.

Keywords: Industry, Covid 19, trends, changes, clothes.

\section{MODA U VREME PANDEMIJE}

Apstrakt: Modna industrija teško je pogođena zbog krize COVID-19. Od materijalnog ka duhovnom. Pandemija je transformisala odnos potrošača sa odećom. $U$ ovom radu je izvršeno istraživanje o tome kako je pandemija uticala na modu, da li će promene u modi nastale kao rezultat pandemije ostati trajne ili ne. Takođe je rađeno istraživanje o pandemijama koje su ranije uticale na svet $i$ kako su uticale na modu, u poređenju sa pandemijom sa COVID-19.

Ključne reči: Industrija, Covid 19, trendovi, promene, odeća.

\section{INTRODUCTION}

The COVID-19 Pandemic, also known as the coronavirus Pandemic, is an ongoing global Pandemic of coronavirus disease 2019 (COVID-19), which is caused by severe acute respiratory syndrome coronavirus 2 (SARS-CoV-2). The virus was first identified in December 2019 in Wuhan, China. The World Health Organization declared a Public Health Emergency of International Concern on 30 January 2020, and later declared a Pandemic on 11 March 2020. As of 24 June 2021, more than 179 million cases have been confirmed, with more than 3.89 million confirmed deaths attributed to COVID-19, making it one of the deadliest Pandemics in history.

The fashion industry has taken a hard hit due to the COVID-19 crisis. From the material to the spiritual. As people were forced to stay at home and retail stores continue to be closed around the world, the demand for clothing has plummeted. It is causing people to reassess and reprioritise what they spend money on. This results in fashion trends slowing down for a while and potentially influence brands to focus on delivering fewer, better quality products to remain profitable. Consumers and brands will have to adapt to a new normal $[1,2,3]$.

The fashion industry faced challenges like the rest of the world, as people lost interest for buying clothes. the things that we're wearing at home, have really increased in sales. And the more professional attire has decreased. People switched to ecommerce, they were already moving in that direction, but this was just a bigger and bigger push. The Pandemic has really pushed on the fashion industry to move forward and to move faster. So increasing the digital reliance of the industry and everyone in the industry.

Vogue editor, Anna Wintour, recently explained that the Pandemic with COVID 19 is alarm for all of us: "I think it's an opportunity for all of us to look at our industry and to look at our lives, and to rethink our values, and to really think about the waste, and 
the amount of money, and consumption, and excess that we have all indulged in and how we really need to rethink what this industry stands for." In this hard Pandemic times some fashion brands struggle to survive, while others have found ways to thrive more than ever. Alessandro Michelle, the creative director of Gucci also thinks that it is time for changes, so he wants to end midseason fashion collections by reducing the number of shows from five to two each year.

Also, design processes are being reconsidered in light of COVID-19. In recent months, some of the most influential members within this stage of the fashion industry, such as the British Fashion Council, Council of Fashion Designers of America, and a group facilitated by Business of Fashion under the mantle Rewiring Fashion, have noted that the Pandemic provides an opportunity to fundamentally overhaul the industry and lead to a completely new, slower, fashion system. As Balmain designer Oliver Rousteing told Vogue, in light of COVID-19, "we are no longer in a time of being the trend of the season. I don't want to be cool, cool's over. Chic's over. You're cool for two months these days. It used to be two years. Who wants to be part of that?". This reimagined industry would be based upon fewer trends, seasons, fashion weeks, and collections. It also aims to support new fashion buying and consumption behaviors and to reduce the industry's dependence on discounting. The biggest impact by Pandemic with COVID-19 will be felt by physical stores, as many customers remain fearful to enter large retail spaces. Moreover, even in countries where direct shopping is still allowed, brands are pivoting fast to digital sales, especially if they want to remain profitable.

However, with all its negative and tragic parts, the arrival of COVID-19 has initiated a bit of positive change. Big brands such as Ralph Lauren, Kenneth Cole, Burberry, and Chanel, are pitching in to help with relief efforts. After a year in which the fashion industry posted record-low economic profits, business leaders are on the front foot, seeking to innovate while continuing to engage their core constituencies. The State of Fashion 2021 report, has remained relatively insulated from the Pandemic, offering consumers a comforting pick-me-up in challenging times.

There is little doubt that 2021 will continue to be tough for many as the COVID-19 Pandemic tracks an uncertain trajectory. Fashion companies that double down on strategy, align with key trends, and reflect an evolving consumer landscape are likely to emerge from the crisis stronger, leaner, and ready to thrive in the next normal. The crisis has accelerated the use of digital and believe that the opportunities and para- digm shifts that have emerged will persevere postcrisis. Companies will communicate, engage, and interact with customers in new ways. At the same time, consumption is changing. Because consumers are looking for purpose and sustainability, a company's mission is becoming more important than ever. And because the next normal is here to stay, fashion companies must be ready to embrace innovation $[4,5,6,7]$.

\section{HISTORY OF PAST PANDEMICS AND HOW THEY INFLUENCED FASHION}

In the realm of infectious diseases, a Pandemic is the worst case scenario. When an epidemic spreads beyond a country's borders, that's when the disease officially becomes a Pandemic.

\subsection{Pandemic (H1N1 virus)}

In the 1918 influenza Pandemic was the most severe Pandemic in recent history. It was caused by an $\mathrm{H} 1 \mathrm{~N} 1$ virus with genes of avian origin. Although there is not universal consensus regarding where the virus originated, it spread worldwide during 1918-1919. In the United States, it was first identified in military personnel in spring 1918. It is estimated that about 500 million people or one-third of the world's population became infected with this virus. The number of deaths was estimated to be at least 50 million worldwide with about 675,000 occurring in the United States. In this time wearing face masks in public was encouraged by health officials (in some places required, with the threat of a $\$ 5$ fine for noncompliance). Through the fall of 1918, sales of blankets, comforters and winter underwear were up, while sales of ready-to-wear and children's wear were hard hit. (Many mothers were afraid to take their children to stores.) Suit sales also dropped.

In that hard Pandemic times woman were wearing a heavy chiffon veil all the time when they were outside on the streets. It may become necessary to order everyone in New York to adopt this measure. These veils were very thick and served as an almost absolute preventative. The veils being chosen take on the color of the hat. Another product, the Safety First Veil, was designed by Stern \& Stern, "a mesh veil with a chiffon border in harem effect," not unlike today's face shields. Wearing gloves was still part of men's and women's etiquette at the time of the Pandemic. The generations that lived through the Spanish flu had come out of veiling, but picked it up again, so it became a perfect excuse to also be able to cover the face. 


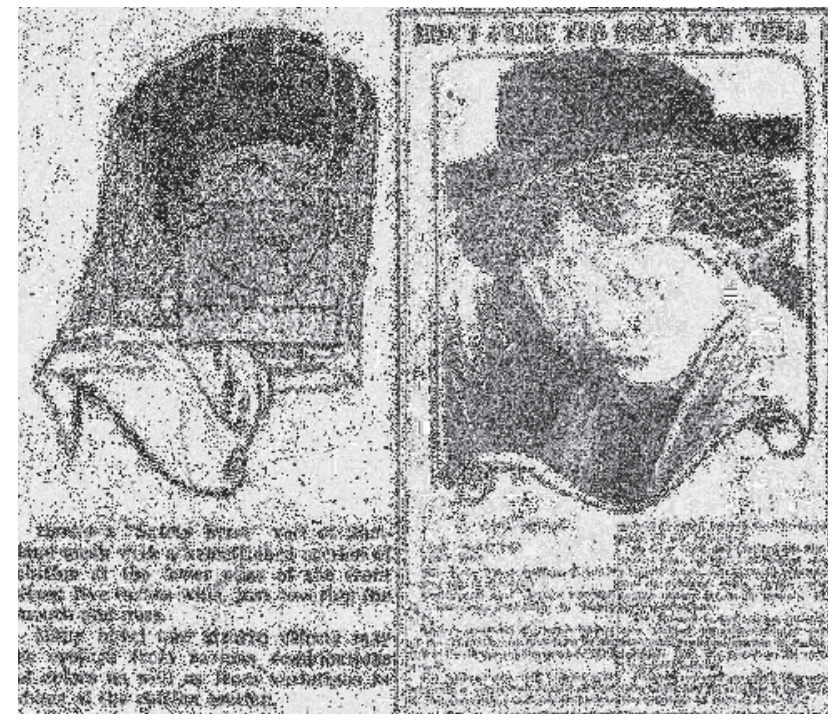

Figure 1. Safety first veil [6]

The face protective masks were made of gauze or even more porous material (Figure 2). In 1918, advanced masks like the N95's that healthcare workers use today were a long way off. Surgical masks were made of gauze, and many people's flu masks were made of gauze too. Red Cross volunteers made and distributed many of these, and newspapers carried instructions for those who may want to make a mask for themselves or donate some to the troops. Still, not everyone used the standard surgical design or material. For instance, Detroit health commissioner J.W. Inches said that gauze masks were too porous to prevent the spread of the flu among the public. Also, masks were most effective when worn properly, which wasn't always what happened $[6,7,8]$.

The 1918-1921 period was a confused era in fashion- there was no obvious progression and it's difficult to accurately date fashion during this period, as opposed to other eras of the 20th century where seasonal changes are easy to recognise. In this time women's increased presence in the workforce would have been

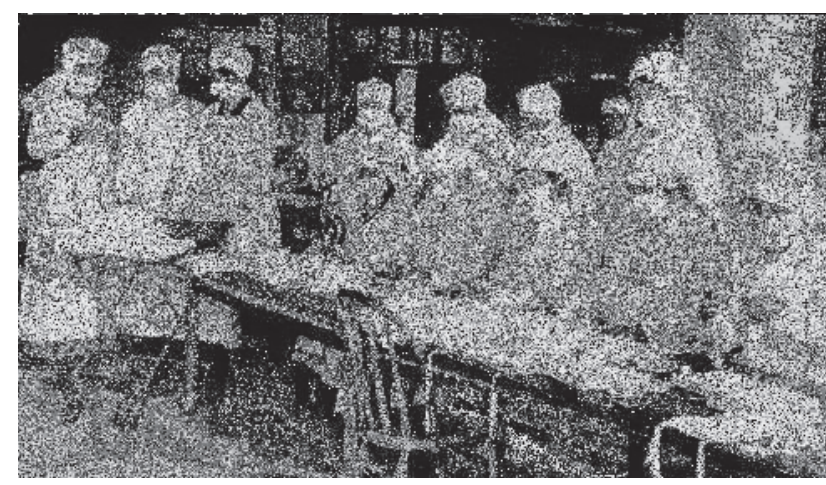

Figure 2. Women working for the Red Cross make masks during the pandemic flu in 1918 [8] far less pronounced without the 1918 Pandemic, particularly in textiles. The increased number of women in textile manufacturing gave rise to a stylistic reorientation, and the 1920s welcomed the success of revolutionary female fashion designers including Coco Chanel, Elsa Schiaparelli, Jeanne Lanvin and Madeleine Vionnet $[9,10]$.

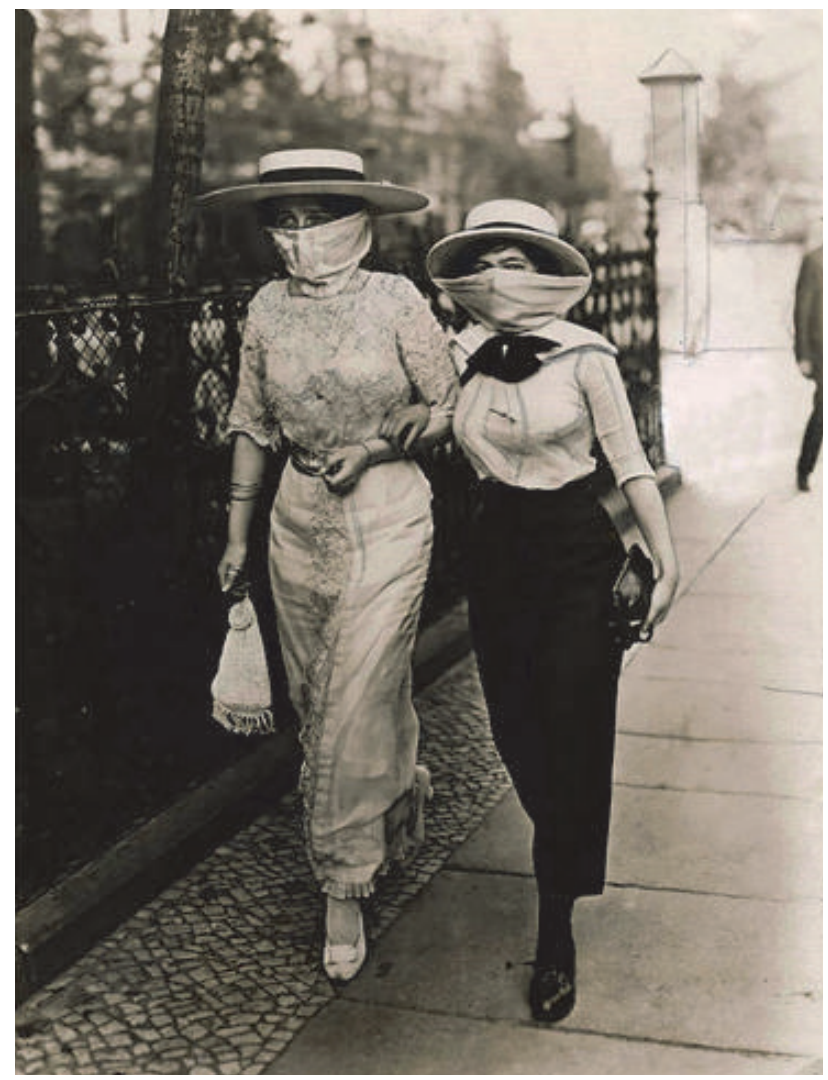

Figure 3. 1918-1919, women walking in London during the Spanish Flu pandemic [9]

\subsection{7- 1958 Pandemic (H2N2 virus)}

In February 1957, a new influenza A (H2N2) virus emerged in East Asia, triggering a Pandemic ("Asian $\mathrm{Flu}^{\prime \prime}$ ). This $\mathrm{H} 2 \mathrm{~N} 2$ virus was comprised of three different genes from an $\mathrm{H} 2 \mathrm{~N} 2$ virus that originated from an avian influenza $\mathrm{A}$ virus, including the $\mathrm{H} 2$ hemagglutinin and the N2 neuraminidase genes. It was first reported in Singapore in February 1957, Hong Kong in April 1957 , and in coastal cities in the United States in summer 1957. The estimated number of deaths was 1.1 million worldwide and 116,000 in the United States. The rapid development of a vaccine against the H2N2 virus and the availability of antibiotics to treat secondary infections limited the spread and mortality of the Pandemic [11,12]. 


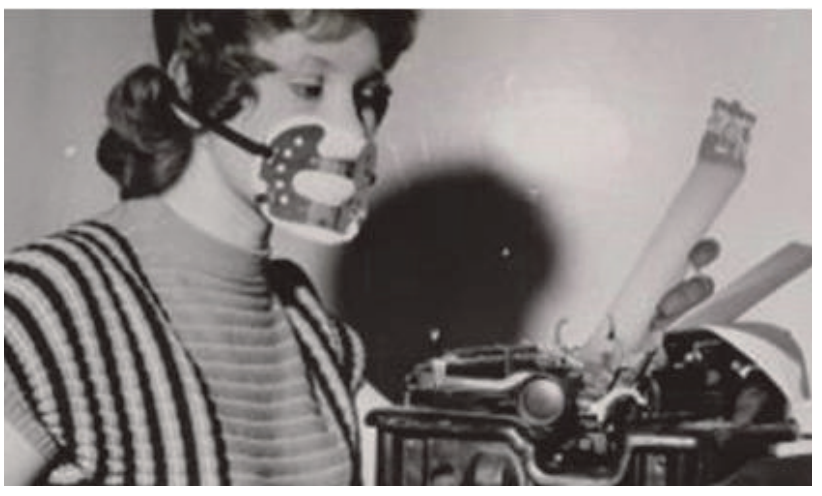

Figure 4. A typist wears a mask to protect against Asian flu in the UK, 1957. Photograph: Daily Herald Archive/SSPL/Getty [11].

People during Asian Flu Pandemic wore masks (Figure 4), but most of the people didn't adopt a sixfeet-apart rule. The Pandemic itself lasted a short time (one year), because a vaccine was discovered very quickly. There is not much written evidence of the impact of this pandemic on fashion, but in general, fashion in the 1950s varied greatly from the beginning to end. Maybe not quite as extreme as the '60s, 1950s fashion saw the introduction of many new styles as well as many styles that paid homage to the 1920s. The waistline was a major issue in the 1950s. Some women really like the snug fit of the Dior dresses while others liked the dresses with no waistline, often referred to as "sack dresses" (Figure 5). The important thing is that people were beginning to feel a little more freedom when it came to their fashion choices. No longer did people feel like they had to conform to a certain look for certain situations. 1957 was the year in which Gabrielle "Coco" Chanel became "an adjective in her own time.

Short, non-fitted suit jackets often strung with brass buttons and pockets, almost always opened to show the blouse inside, sleeves peeled back to show a shirt's cuffs, magnificent fakes, "pearls" and colored stones looped round the throat, or a jeweled Maltese cross winking on a lapel, Bretons perched on the back of the head, pull-overs that matched a jacket's lining, jerseys, tweeds, brocades, lace evening dresses- all were stamped with elegant nonchalance. The best news about the new fashion for many men who bemoaned the disappearance of the female waistline was that it meant higher hemline. And that in turn meant the longer the leg, the lower the heel of the shoe, and women finally started climbing down from the stiletto heel, but still clung to the stiletto toe [13].

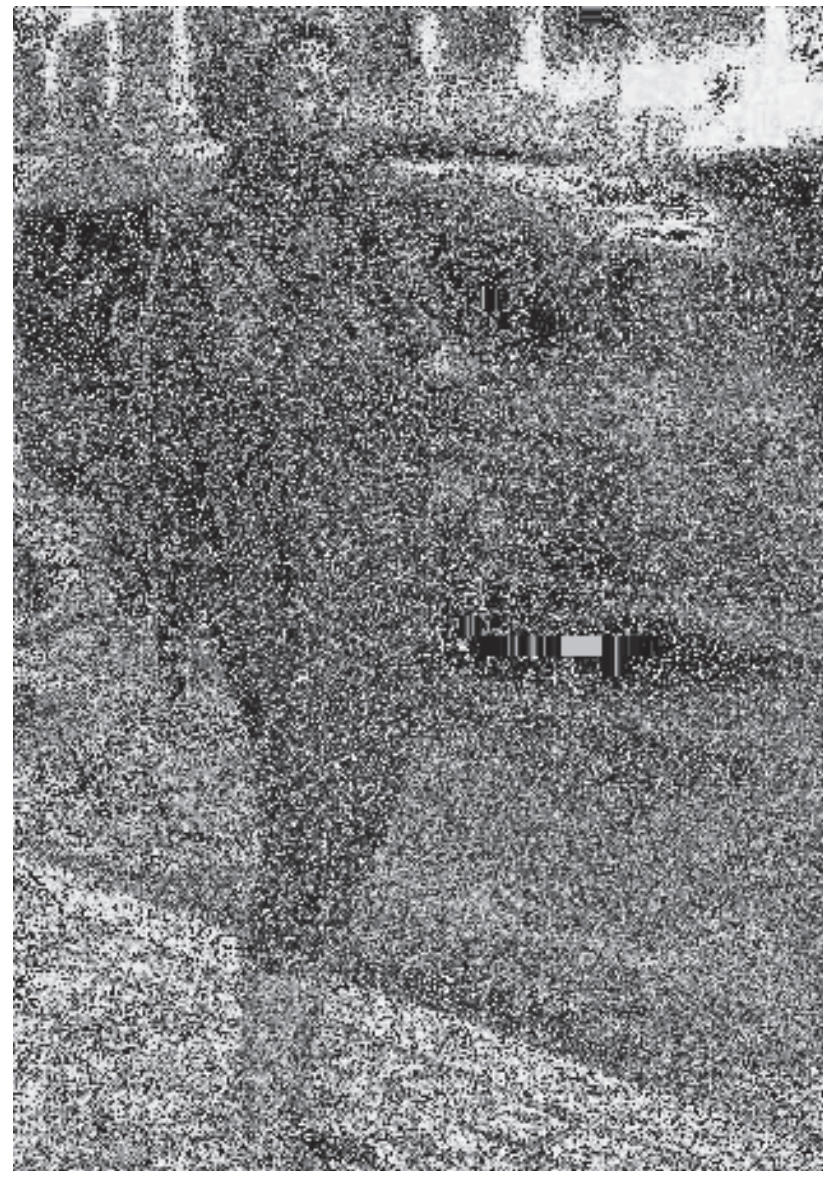

Figure 5. 1957 "Sack Dress" [13]

\subsection{Pandemic (H3N2 virus)}

The 1968 Pandemic was caused by an influenza A (H3N2) virus comprised of two genes from an avian influenza A virus, including a new $\mathrm{H} 3$ hemagglutinin, but also contained the $\mathrm{N} 2$ neuraminidase from the $1957 \mathrm{H} 2 \mathrm{~N} 2$ virus. It was first noted in the United States in September 1968. The estimated number of deaths was 1 million worldwide and about 100,000 in the United States. Most excess deaths were in people 65 years and older. The 1968 flu Pandemic was a global outbreak of influenza that originated in China in July 1968 and lasted until 1969-70. The Division of Biologics Standards of the National Institutes of Health provided the A/Hong Kong/1968 (H3N2) vaccine virus to manufacturers in August 1968. However, before manufacturers had completed studies to determine its feasibility for producing a Pandemic vaccine, a new vaccine virus became available. This virus, the Aichi strain from Japan, demonstrated superior vaccine production potential and was supplied to manufacturers on September 9, 1968, and incorporated into a monovalent Pandemic influenza vaccine $[14,15,16,17]$. 


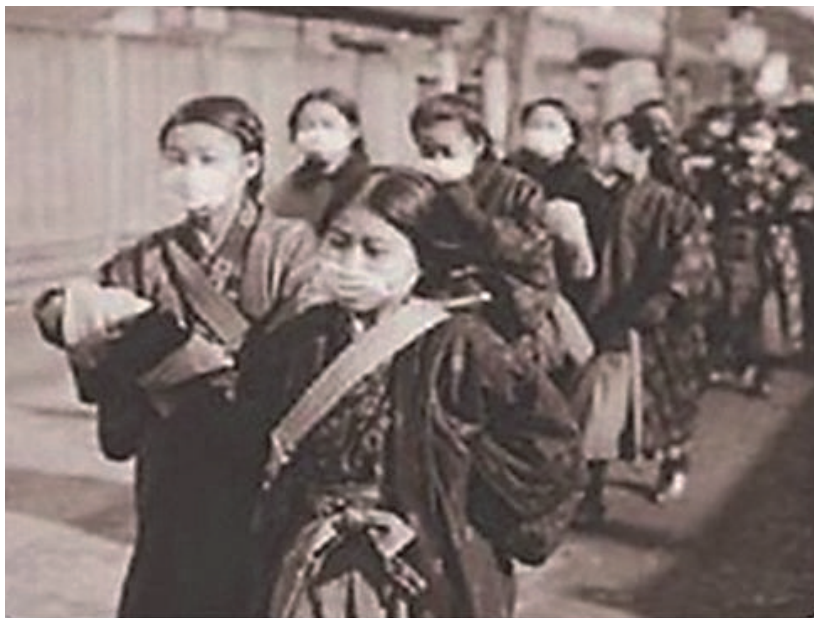

Figure 6. Hong Kong Flu 1968-1969 [18]

Even with those relaxed ideas about viruses, the Hong Kong flu caught the world by surprise. It was different from previous Pandemics because of how fast it spread, thanks largely to increased international air travel. The Hong Kong flu also arrived at a particularly volatile moment in history. There was the race to land a man on the moon and political assassinations and sexual liberation and the civil rights movement. But, even if people in 1968 had been told to stay home, it's unlikely they would've protested [18]. People wore masks to protect their self from the virus spreading (Figure 6). The impact of this Pandemic on fashion was not significant as the Pandemic in 1918. Fashion in the 1960s became progressively more casual across all genders and ages. Womenswear followed three broad trends: a continuation of the previous decade's ladylike elegance, the youthful styles of Mary Quant and the Space Age influence, and the late 1960s "hippie" style. Menswear saw an increasing amount of color and pattern (Figure 8), military influence, and new fashion icons in the form of rock stars. Children's wear saw less change, but also became more casual and bright in color and pattern. Skimmer dresses were very popular (Figure 7). They fit straight on the body with a high neckline and (usually) a belt to define the waist, but not shape it. They "skimmed" the body without touching the skin. They also hovered above the knee.

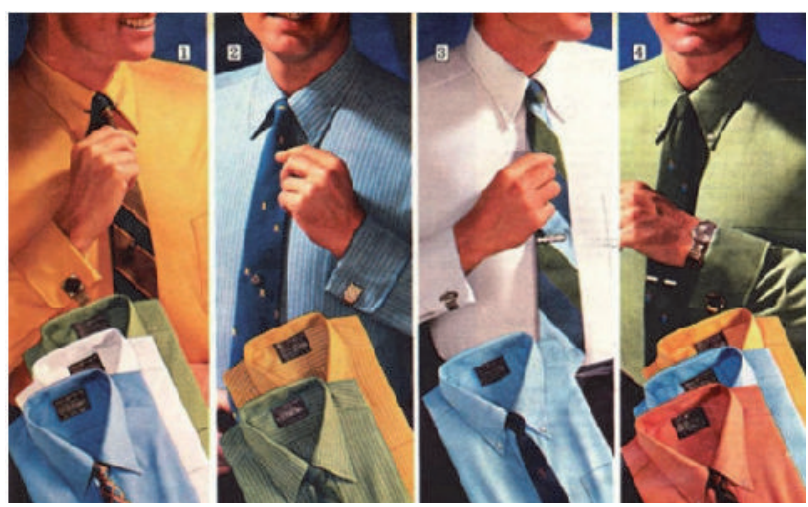

Figure 8. 1968 Colored Shirts, Skinny Ties, and Cufflinks, source: vintage dancer [20]

Found in a variety of fabrics colors and patterns, the "dirndl skirt" was appropriate for work or play. Mut-

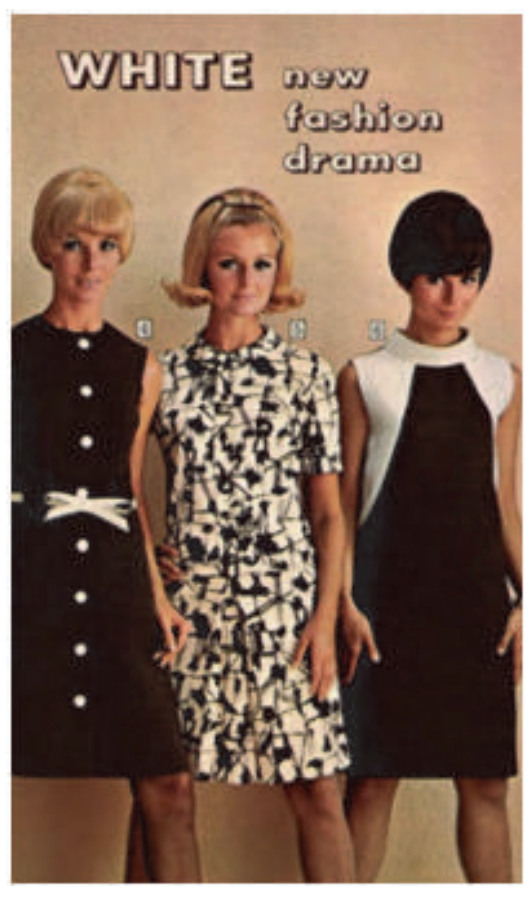

a)

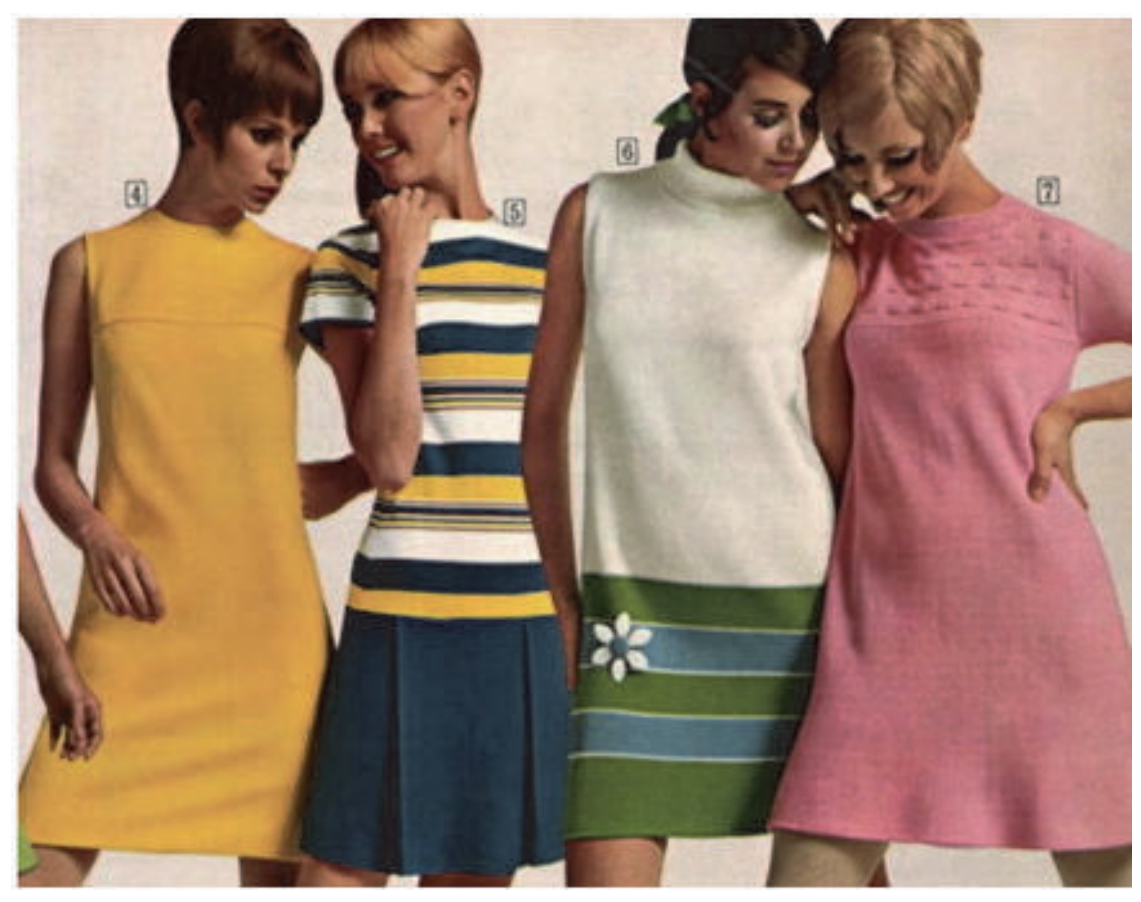

b)

Figure 7. a) 1968 Skimmer Dress With Tie Belt, Drop Waist Dress, and Shift Dress b) 1968 Knit Shift Dresses for Women, source: vintage dancer [19] 
ed shades and glen plaids were particularly popular in blends that give a linen look. Gently gathered at the waistline, one dirndl in gray rayon-silk blended fabric was topped with a blue and black tattersall shirt of cotton oxford cloth. The waistline was accented with a belt, ever-present this year. For variety, pleated, flared and A-line skirts were still popular with the emphasis remaining on the waistline. Belts and cummerbunds are added to achieve the 1968 look $[19,20]$.

\subsection{H1N1 Pandemic (H1N1 pdm09 virus)}

In the spring of 2009, a novel influenza A (H1N1) virus emerged. It was detected first in the United States and spread quickly across the United States and the world. This new H1N1 virus contained a unique combination of influenza genes not previously identified in animals or people. This virus was designated as influenza A (H1N1)pdm09 virus. Ten years later work continues to better understand influenza, prevent disease, and prepare for the next Pandemic. Though the 2009 flu Pandemic primarily affected children and young and middle-aged adults, the impact of the (H1N1)pdm09 virus on the global population during the first year was less severe than that of previous Pandemics. Estimates of Pandemic influenza mortality ranged from 0.03 percent of the world's population during the $1968 \mathrm{H} 3 \mathrm{~N} 2$ Pandemic to 1 percent to 3 percent of the world's population during the 1918 H1N1 Pandemic. It is estimated that 0.001 percent to 0.007 percent of the world's population died of respiratory complications associated with (H1N1)pdm09 virus infection during the first 12 months the virus circulated. The 2009 swine flu Pandemic was an influenza Pandemic that lasted about 19 months, from January 2009 to August 2010.

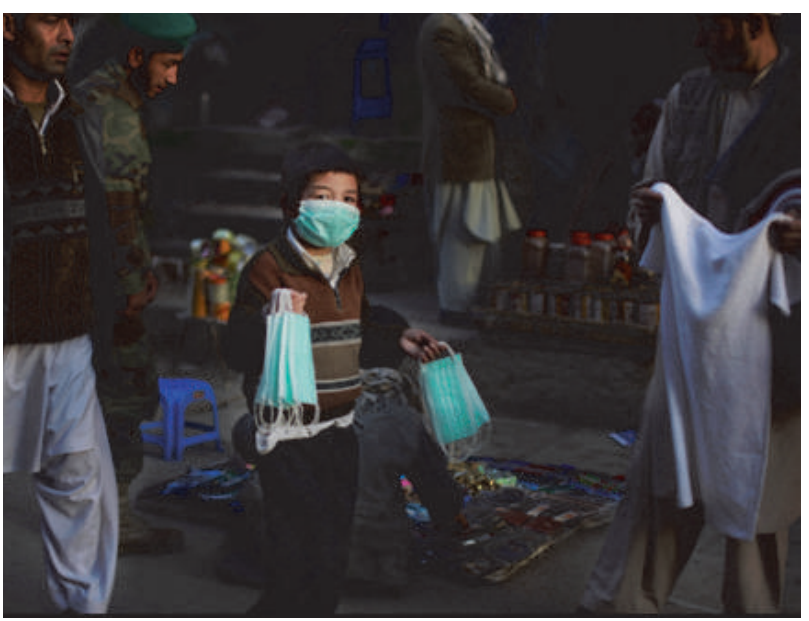

Figure 9. An Afghan boy tries to sell protective masks on a market in Kabul [22]
For people was hard to find the essential effectiveness of a face mask, and also thought that social distancing was effective, as well as keeping space 6 feet was recommended between people.

People in this Pandemic times felt bored of plain blue or dull green medical masks like before, some Mexicans have taken to customising their facial gear, so they looked very fashionable and stylish $[21,22,23]$.

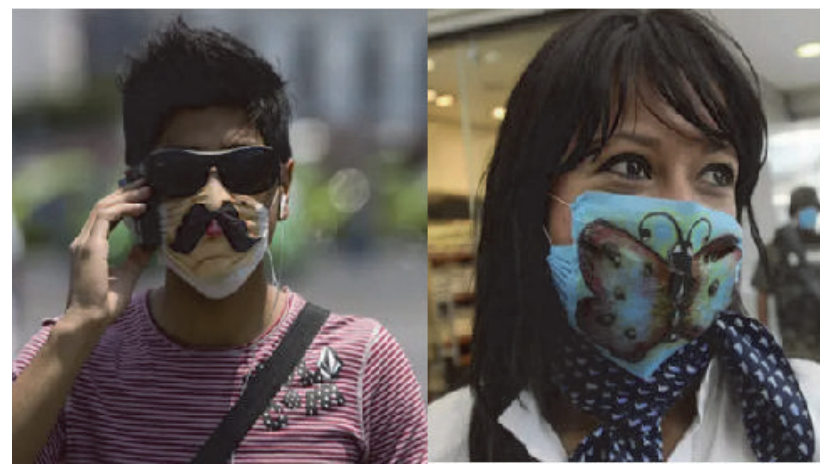

Figure 10. Swine flu: custom face masks take to Mexico's streets [23]

\section{COVID-19 PANDEMIC (CURRENT)}

The COVID-19 Pandemic, also known as the coronavirus Pandemic, is an ongoing global Pandemic of coronavirus disease 2019 (COVID-19), which is caused by severe acute respiratory syndrome coronavirus 2 (SARS-CoV-2). The virus was first identified in December 2019 in Wuhan, China. The World Health Organization declared a Public Health Emergency of International Concern on 30 January 2020, and later declared a Pandemic on 11 March 2020. As on 29 June 2021, more than 181 million cases have been confirmed, with more than 3.92 million confirmed deaths attributed to COVID-19, making it one of the deadliest Pandemics in history.

Although the exact origin of the virus is still unknown, [24] the first outbreak started in Wuhan, Hubei, China in late 2019 [25,26,27]. On 11 February 2020, the World Health Organization (WHO) named the disease "COVID-19", which is short for coronavirus disease 2019 [28,29,30,31].

\subsection{COVID-19 fashion: Out with the dress code}

One of the many industries not immune to the effects of COVID-19 was the fashion industry. Granted, there was a major spike in online sales and a demand for comfortable "work from home" clothes, but it wasn't enough to make up for the overall drop in sales and hit on the global economy. The industry faced challenges like the rest of the world, as people lost interest for buying clothes. Many brands stopped working with overseas manufactures because it was too expensive, which also inspired 
consumers to shop more consciously. While not as comfortable, high fashion was also forced to have an online focus, especially during fashion weeks [32].

\subsection{Will the COVID-19 Pandemic change how people dress for work in the future?}

With nowhere to go and hardly anyone to impress, the vast majority of people in the time of Pandemia with Covid -19, spent more time in their pajamas than they would care to admit. And it wasn't just pajamas for sleeping. Finding themselves in an extended period of remote work, professionals traded in their heels and loafers for fuzzy socks and slippers, swapped their tailored suits and blazers for comfy sweatshirts and joggers. People start prioritizing comfort over style, forgoing buying trendy clothes for basic apparel in neutral colors and comfortable fabrics, so It's going to be very hard to get people back into those uncomfortable clothes after a really long time of wearing comfortable clothes. But because people are hardwired for social feedback, it's also possible that when things do return to normal after the Pandemic, consumers will want to reinvent themselves again, propelling renewed demand for stylish wares [33].

\subsection{The street style is defined with the Same Accessory: A Mask}

Street style has undoubtedly been one of the biggest phenomena to revolutionize the fashion industry. It formed careers, transformed fashion week and infiltrated mainstream media. The global Pandemic has forced the fashion industry to re-evaluate its entire way of working, which includes finding new, often digital modes of showcasing designer's new collections. What does this mean for street style? Can it still be relevant in the age of social distancing? The Pandemic with COVID -19 taught us to see fashion and function coming closer together (Figure 12). How to dress while having a limited social life is the biggest question. Though the streets may be quiet, there are still trends to track. One worth investigating is the reemergence of utility wear, which offers fashion, convenience, and a sense of preparedness in a time of uncertainty. All of those pockets are useful for the must-haves of the moment, mini hand sanitizers and spare masks included [33,34].

\subsection{Trending: work-from-home wear}

The Pandemic, almost overnight, elevated the need for comfortable leisure wear, as people work, live and play from their homes. Athleisure has been hot for a while, but it's only a branch of this larger evolution.

Comfort dressing -or 'quarantine style -was a fashion force to be reckoned with during COVID-19. Tom Simpson, fashion director of online retailer The Iconic, said they saw a "huge demand" for athleisure brands when the country first went into lockdown. "If there was a number one item in fashion in Australia in the past six months, it was a sweat top and a pair of sneakers," so, "It's made people realise that you can dress more comfortably, and still work well." One of Australia's most popular active wear labels, P.E Nation, saw a similar surge. "There has been a massive spike in sales of hoodies, sweats and track pants, along with the consistent sell through of leggings and active looks across the board."

The lockdown mentality and work from home situation has impacted our way of life for good. The comfortable and functional fashion came as priority, so we start to accept a bit more of a relaxed dress code. In this Pandemic time we all have learned that productivity of our daily work, does not relate with how we are dressed. People start to care more about the material of the clothes they are wearing. When it comes to dresses and skirts and knits look for ribbed styles which are more comfortable, or a jumper dress. Pip Edwards from P.E. Nation suggested some unusual combination that most of the people didn't wore before the Pandemic - pairing leggings with a tailored jacket when returning to the office so, the people would feel much more comfortable, as at the moments they work online from home (Figure 13).

The lienen which is causal but comfortable material came in trend, and Linen suits for both men and women became very trendy. Loose-fit tailoring is also very much on trend, for work and the bar, so look for looser-fit trousers and blazers. With one word - Comfort is king in these hard days of Pandemic with COVID-19 [35, 36].

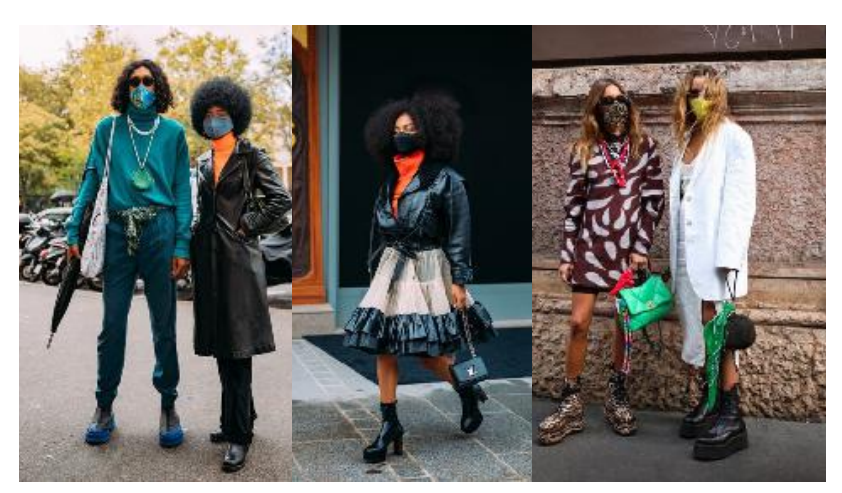

Figure 12. Street style in the time of Pandemic [34] 


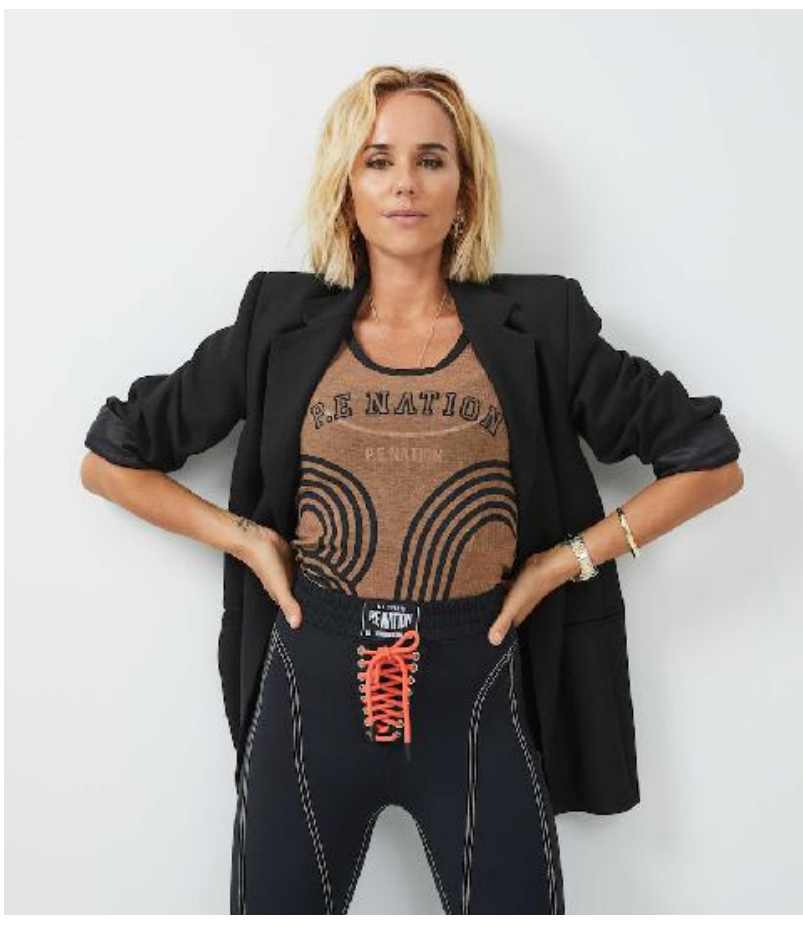

Figure 13. Pip Edwards from P.E. Nation suggested pairing leggings with a tailored jacket when returning to the office [36].

\subsection{Post Pandemic fashion predictions}

Fashion designers are looking into the post-Pandemic future and predicting what we'll want to wear when we no longer have to spend most of our time at home. In fashion, there has already been a wave of heated debate about what to expect in the post-Pandemic world. When it hit, COVID-19 caused demand for tracksuits, pajamas, hoodies and sportswear.

Many have drawn parallels between the COVID-19 Pandemic and a century ago, during the 1918 Spanish flu. After the First World War and one of history's deadliest epidemics we had a decade of social freedom, creative boom and economic upturn.

Fashion stood nearly still from the fall of 1918 to the fall of 1920 with almost no changes in silhouette or novelty," says Jonathan Walford, curatorial director at the Fashion History Museum. He says that in the era that followed - the roaring 20 s - fashion reflected a society driven by hedonism and a desire to look youthful. Instead of suits men began wearing "sports clothes, caps, trousers and argyle sweaters". While women "wore oversized hats that slipped down over their bobbed hair and the beaded, waist less, sleeveless dresses which made them look like they were playing dress up in their mother's gowns". In our own "roaring 20s" the way that we dress will be informed by a new sense of freedom $[35,36]$. In the light of the above, it's no surprise that most conversations about the future of fashion circle conscientiousness. 'Buying less and better' will prevail. Brands that are able to reorient their missions and business models in more sustainable ways will be able to cater to a more captive audience. Even before the Pandemic hit, brands like Gucci, Gabriela Hearst, Stella McCartney, and Anita Dongre have committed themselves to sustainability and have led efforts that include researching for sustainable alternatives for fur, reusing discarded clothes, and working towards decreasing their carbon footprints. Now more than ever, it is time to follow through on these.

No matter how long the Pandemic lasts, the fashion world is mobilizing to combat it in thoughtful ways while retaining creativity at its heart. But one undeniable thing is that the landscape stands changed forever $[37,38]$.

\section{CONCLUSION}

The fashion industry has taken a hard hit due to the COVID-19 crisis. As people were forced to stay at home and retail stores continue to be closed around the world, the demand for clothing has plummeted. It is causing people to reassess and reprioritise what they spend money on. This results in fashion trends slowing down for a while and potentially influence brands to focus on delivering fewer, better quality products to remain profitable. Consumers and brands will have to adapt to a new normal. The fashion industry faced challenges like the rest of the world, as people lost interest for buying clothes. the things that we're wearing at home, have really increased in sales. And the more professional attire has decreased. From the past Pandemics, and the curent Pandemic (COVID - 19) in terms of fashion and clothes, the following can be concluded:

- In the 1918 influenza Pandemic was the most severe Pandemic in recent history. It was caused by an $\mathrm{H} 1 \mathrm{~N} 1$ virus with genes of avian origin. Although there is not universal consensus regarding where the virus originated, it spread worldwide during 1918-1919. In that hard Pandemic time woman were wearing a heavy chiffon veil all the time when they were outside on the streets. These veils were very thick and served as an almost absolute preventative.

- The 1918-1921 period was a confused era in fashion- there was no obvious progression and it's difficult to accurately date fashion during this period, as opposed to other eras of the 20th century where seasonal changes are easy to recognise. In this time women's increased presence in the workforce would have been 
far less pronounced without the 1918 Pandemic, particularly in textiles.

- In February 1957, a new influenza A (H2N2) virus emerged in East Asia, triggering a Pandemic ("Asian Flu").

- People during Asian Flu Pandemic wore masks but most of the people didn't adopt a six-feet-apart rule. There is not much written evidence of the impact of this pandemic on fashion, but in general, fashion in the 1950 s varied greatly from the beginning to end. Maybe not quite as extreme as the '60s, 1950s fashion saw the introduction of many new styles as well as many styles that paid homage to the 1920s. The waistline was a major issue in the 1950s. Some women really like the snug fit of the Dior dresses while others liked the dresses with no waistline, often referred to as "sack dresses." The important thing is that people were beginning to feel a little more freedom when it came to their fashion choices.

- The 1968 Pandemic was caused by an influenza A (H3N2) virus comprised of two genes from an avian influenza $\mathrm{A}$ virus, including a new $\mathrm{H} 3$ hemagglutinin, but also contained the N2 neuraminidase from the 1957 H2N2 virus. The impact of this Pandemic on fashion was not significant as the Pandemic in 1918. Fashion in the 1960s became progressively more casual across all genders and ages. Womenswear followed three broad trends: a continuation of the previous decade's ladylike elegance, the youthful styles of Mary Quant and the Space Age influence, and the late 1960s "hippie" style. Menswear saw an increasing amount of color and pattern, military influence, and new fashion icons in the form of rock stars. Children's wear saw less change, but also became more casual and bright in color and pattern. Skimmer dresses were very popular.

- In the spring of 2009, a novel influenza A (H1N1) virus emerged. It was detected first in the United States and spread quickly across the United States and the world. People in this Pandemic times felt bored of plain blue or dull green medical masks, some Mexicans have stepped forward in fashion and taken to customising their facial gear, so they looked very fashionable and stylish.

- The COVID-19 Pandemic, also known as the coronavirus Pandemic, is an ongoing global Pandemic of coronavirus disease 2019 (COVID-19). One of the many industries not immune to the effects of COVID-19 was the fashion industry. Granted, there was a major spike in online sales and a demand for comfortable "work from home" clothes, but it wasn't enough to make up for the overall drop in sales and hit on the global economy. The industry faced challenges like the rest of the world, as people lost interest for buying clothes. People start prioritizing comfort over style, forgoing buying trendy clothes for basic apparel in neutral colors and comfortable fabrics. Street style has undoubtedly been one of the biggest phenomena to revolutionize the fashion industry. The Pandemic, almost overnight, elevated the need for comfortable leisure wear, as people work, live and play from their homes. Athleisure has been hot for a while, but it's only a branch of this larger evolution.

- The Pandemic with Covid -19 taught us to see fashion and function coming closer together People start to care more about the material of the clothes they are wearing. When it comes to dresses and skirts and knits look for ribbed styles which are more comfortable, or a jumper dress.

- Fashion designers are looking into the post-Pandemic future and predicting what we'll want to wear when we no longer have to spend most of our time at home. In fashion, there has already been a wave of heated debate about what to expect in the post-Pandemic world. 'Buying less and better' will prevail. Brands that are able to reorient their missions and business models in more sustainable ways will be able to cater to a more captive audience.

- No matter how long the Pandemic lasts, the fashion world is mobilizing to combat it in thoughtful ways while retaining creativity at its heart. But one undeniable thing is that the landscape stands changed forever.

\section{REFERENCES}

[1] Fashion's Future: The Sustainable Development Goals. Online Courses Business \& Management.

(https://www.futurelearn.com Available: 01.07.2021).

[2] Fashion revolution impact report. (2020). (https: Ilwww.fashionrevolution.org. Available: 01.07.2021).

[3] Akbar H. (29 April 2020). Coronavirus: Two million Bangladesh jobs 'at risk' as clothes orders dry up. (https:IIwww.bbc.com/news/worldasia-52417822 Available: 25.06.2021).

[4] COVID-19 and its impact on society. (2021). (https: Ilwww.openaccessgovernment.org/covid-19-and-its-impact-on society/110928/ Available: 30.06 .2021 ). 
[5] Chim B., Antonio G., Hanna G., Miriam L., Karl-Hendrik M. (2020). A perfect storm for fashion marketplaces. (https:Ilwww.mckinsey.com. Available: 01.07.2021).

[6] From WWD Archives: The Impact of the Spanish Flu of 1918 on Fashion (https://wwd.com/fashion-news/fashion-features/gallery/from-wwdarchives-the-impact-of-the-spanish-flu-of-1918on-fashion-1203646734/ Available: 04.07.2021).

[7] Taylor B., Monique R., Mary H., (2020). Will COVID-19 support the transition to a more sustainable fashion industry? Sustainability: Science, Practice and Policy, Vol. 16 (1), 298-308.

[8] Becky I. (2020). When mask-wearing rules in the 1918 Pandemic faced resistance. Most people complied, but some resisted or poked holes in their masks to smoke (https: Ilwww.history.com. Available: 02.07.2021).

[9] Madeline. R. (2020). It was a cultural reset. (https:// www.miista.com/es/it-was-a-cultural-resetwhat-we-can-learn-from-the-1918-spanish-influenza/ Available: 04.07.2021).

[10] Isabella R. (2020). Asking About Masking: Uncovering Spanish Flu Mask Fashion. (Available: https:// www.costumesociety.org.uk. 28.06.2021).

[11] Mullally U. (2020). An 'Asian flu' pandemic closed 17 Dublin schools in 1957. From the archive: The Southside of the city was hit harder than less populous Northside. (https://www.Irishtimes. com Available: 04.07.2021).

[12] Epidemic Observation Unit. Retrospective survey of the 1957 epidemic of Asian influenza. J Coll Gen Pract Res Newsl. p. 254-261.

[13] 1950s Fashion: Styles, trends, pictures \& history. (https://www.retrowaste.com/1950s/fashion-inthe-1950s/ Available: 28.06.2021).

[14] Barbara J. Jester., Timothy M. Uyeki., Daniel B. Jernigan. (2020). Fifty Years of Influenza A (H3N2) Following the Pandemic of 1968. Am J Public Health, 110(5), 669-676.

[15] Chang W. K. National Influenza Experience in Hong Kong, 1968. Bulletin of the World Health Organization 41. 1969(3), 349-351.
[16] Cockburn W. C., Delon P. J., (1969). Ferreira W. Origin and Progress of the 1968-69 Hong Kong Influenza Epidemic. Bulletin of the World Health Organization 41 (3), 345-348.

[17] Kadri Z. N. (1970). An Outbreak of 'Hong Kong 'Flu' in Singapore, I. Clinical Study. Singapore. Medical Journal 11. (1), 30-32.

[18] Influenza 1968-1969 Hong Kong Flu. (https:// www.geni.com/projects/Influenza-1968-1969Hong-Kong-Flu/28167 Available: 02.07.2021).

[19] Vintagedancer. (https://vintagedancer. com/1960s/1960s-fashion-womens/ Available: 03.07.2021).

[20] Vintagedancer. 1960s Men's Fashion, 60s Fashion for Men. (https://vintagedancer. com/1960s/1960s-mens-fashion/ Available: 04.07.2021).

[21] 2009 H1N1 PandemicH1N1pdm09 virus (https://www.cdc.gov/flu/pandemic-resources/2009-h1n1-pandemic.html Available 05.07.2021).

[22] Watching the H1N1 flu pandemic. (http://lollitop. blogspot.com/2010/02/watching-h1n1-flu-pandemic_02.html Available 05.07.2021).

[23] Swine flu: custom face masks take to Mexico's streets (https://www.theguardian.com/world/ gallery/2009/may/01/mexico-swine-flu1 Available: 04.07.2021).

[24] Kelvin Kai-W., Sridhar., Siddharth., Chiu., Kelvin Hei-Y., Hung., Derek Ling-L., Li, Xin., Hung., Ivan Fan-Ngai., Tam., Anthony R., Chung., Tom Wai-H., Chan., Jasper Fuk-W., Zhang, Anna Jian-Xia., Cheng., Vincent Chi-C., Yuen., Kwok-Y. (2021). Lessons learned 1 year after SARS-CoV-2 emergence leading to COVID-19 Pandemic. Emerging Microbes \& Infections. 10 (1), 507-535.

[25] Hu., Ben., Guo, Hua., Zhou., Peng., Shi., Zheng-Li. (2020). Characteristics of SARS-CoV-2 and COVID-19. Nature Reviews. Microbiology. 19 (3), 141154. 
[26] Graham, Rachel L., Baric, Ralph S., (19 May 2020). SARS-CoV-2: Combating Coronavirus Emergence. Immunity. 52 (5), 734-736.

[27] Adhanom, T. (2020). WHO Director-General's remarks at the media briefing on 2019-nCoV on 11 February 2020. World Health Organization (WHO).

[28] Lovelace Jr, B. (2020). World Health Organization names the new coronavirus: COVID-19. CNBC.

[29] Perlman S. (2020). Another Decade, Another Coronavirus. The New England Journal of Medicine. $382(8), 760-762$.

[30] Hu B., Guo H., Zhou P., Shi Zheng-L. (2020). Characteristics of SARS-CoV-2 and COVID-19. Nature Reviews. Microbiology. 19 (3), 141-154.

[31] Graham., Rachel L., Baric., Ralph S. (2020). SARSCoV-2: Combating Coronavirus Emergence. Immunity. 52 (5), 734-736.

[32] Savannah F. (2020). COVID-19 Impact: How the pandemic changed the fashion industry.

[33] Daniele Fay M. Will the Covid-19 Pandemic change how people dress for work in the future? Northeastern University. (https:IIwww.Damore-mckim.northeastern.edu. Available: 03.07.2021).
[34] This Season's Best Street Style Photos All Include the Same Accessory: A Mask (https://www.vogue. com/slideshow/street-style-masks-spring-2021 Available: 01.07.2021).

[35] Hannah B. W. (2020). Street Style Was Already Tired, And Now The Pandemic Has Killed It Completely.

[36] Midena K. (2020). Working from home during COVID-19 is changing what we're wearing in the office - and going back is like 'casual Friday every day. (https: \|www.abc.net.au. Available: 03.07.2021).

[37] Priya E. (2020). Roaring 20s: fashion world predicts post-Covid boom. (https: IIwww.theguardian.com Available: 02.07.2021).

[38] Fashion Post COVID-19. (https:IIwww.lifestyleasia. com Available: 04.07.2021).

Primljeno/Received on: 04.07.2021.

Revidirano/ Revised on: 15.08.2021.

Prihvaćeno/Accepted on: 16.08.2021.

(c) 2021 Authors. Published by Union of Textile Engineers and Technicians of Serbia. This article is an open access article distributed under the terms and conditions of the Creative Commons Attribution 4.0 International license (CC BY) (https://creativecommons. org/licenses/by/4.0/) 